\title{
ELECTROOXIDATION OF 2,4,6-TRICHLOROPHENOL ON GLASSY CARBON ELECTRODES MODIFIED WITH COMPOSITE $\mathrm{Ni}(\mathrm{OH})_{2}-\mathrm{Co}(\mathrm{OH})_{2}$ FILMS
}

\author{
THAÍS GONZÁLEZI, RICARDO SALAZAR', JOSÉ F. MARCO², C. GUTIÉRREZ², \\ M. SOLEDAD URETA-ZAÑARTU ${ }^{\prime *}$
}

\begin{abstract}
${ }^{1}$ Departamento de Ciencias del Ambiente, Facultad de Química y Biología, Universidad de Santiago de Chile, C. Libertador Bernardo O'Higgins 3363, Estación Central, Santiago, Chile. Casilla 40, correo 33, Santiago, Chile. Phone 56227181162

2Instituto de Química Física "Rocasolano”, CSIC, C. Serrano, 119, 28006-Madrid, Spain
\end{abstract}

(Received: July 26, 2013 - Accepted: September 3, 2013)

\begin{abstract}
Glassy carbon electrodes coated with a film of electrodeposited cobalt and nickel hydroxides were prepared in order to determine its activity to the 2,4,6-trichlorophenol (TCP) oxidation. The modified electrodes were characterized by cyclic voltammetry (CV), electrochemical impedance spectroscopy (EIS), X-ray photoelectron spectroscopy and Scan Electron Microscopy (SEM) with Energy Dispersive X-ray Spectroscopy (EDS). The results indicate that both hydroxides are homogeneously distributed in the electrode surface. From the viewpoint of electrochemical oxidation of TCP, the presence of cobalt and nickel hydroxides on the electrode surface (i) promotes a more complete oxidation of TCP and (ii) decreases the fouling of the electrode surface in comparison with GC and GC modified with Ni or Co separately.
\end{abstract}

Keywords: Modified electrodes, (Ni-Co) hydroxides, chlorophenol oxidation

\section{1.- INTRODUCTION}

Waste from domestic, agricultural and industrial activities such as cellulose treatment and the manufacturing of plastics, adhesives and petrochemicals may pollute watercourses [1]. The widely used halogenated compounds are not amenable to biological degradation, and can accumulate in living organisms, this being the reason why they are used as wood preservatives, antibacterial agents, fungicides, insecticides and herbicides [2,3].

$\mathrm{Au}$ and $\mathrm{Pt}$ show high catalytic activity for the electrooxidation of chlorophenols (CP) over short times, but they are quickly fouled up by small oligomers, generated by the coupling of two phenoxy radicals or by reaction of a radical with unreacted $\mathrm{CP}$ molecules [4,5]. Electrodes modified with redox mediators could increase the activity and specificity for a given reaction and avoid fouling [6]. So, glassy carbon (GC) electrodes modified with $\mathrm{Co}(\mathrm{II})$ phthalocyanine $(\mathrm{CoPc})$ show higher currents and less fouling in the oxidation of 2-chlorophenol (2-CP) and 4-chlorophenol (4-CP) in $1 \mathrm{M}$ $\mathrm{NaOH}$ [7]. Also Alatorre et al. [8] found that GC electrodes modified with electropolymerized nickel complexes showed less fouling in the oxidation of 4- $\mathrm{CP}$ and 4-nitrophenol in $1 \mathrm{M} \mathrm{NaOH}$. Our laboratory has some experience in this field $[4,5,9,10,11]$. The goal is to decrease the oligomerization rate and to promote full oxidation of the phenolic compound.

The redox mediator activity in alkaline media of electrodes modified with $\mathrm{Ni}(\mathrm{II})$ compounds is due to the quasi reversible properties of the $\mathrm{Ni}(\mathrm{III}) / \mathrm{Ni}(\mathrm{II})$ process $[9,10,11]$, which may be represented as follows [12]:

$$
\mathrm{Ni}(\mathrm{OH})_{2}+\mathrm{OH}^{-} \rightarrow \mathrm{NiOOH}+\mathrm{H}_{2} \mathrm{O}+\mathrm{e}^{-}
$$

Actually nickel hydroxide can have more than one stable structure $[13,14,15]$. Van der Ven et al. [16] reported the formation of two types of nickel hydroxide, $\alpha$ - and $\beta-\mathrm{Ni}(\mathrm{OH})_{2}$, and two kinds of nickel oxyhydroxides, $\alpha$ - and $\gamma-\mathrm{NiOOH}$, which, due to their different structures and degrees of hydration, have different electrochemical properties.

Other hydroxide, $\mathrm{Co}(\mathrm{OH})_{2}$, has been widely used as an additive to $\mathrm{Ni}(\mathrm{OH})_{2}$ in order to improve alkaline secondary batteries $[17,18,19]$, these improvements being attributed to an increase of both ionic and electronic conductivities. Jafarian et al. [20] have reported a good oxidation of methanol at glassy carbon electrodes modified with cobalt hydroxide. Nickel-cobalt hydroxides electrodes can oxidize methane [21] and indirectly chlorophenols [22]. Vidotti et al. [23] reported that ITO electrodes modified with nanostructured hydroxides of nickel and cobalt were very active for the oxidation of urea and Yan et al. [24] found that the overpotential for urea oxidation of a ( $\mathrm{Ni}-\mathrm{Co}$ )-hydroxide electrode was $150 \mathrm{mV}$ lower than that of a Ni hydroxide electrode.

In this work we have prepared and characterized glassy carbon electrodes modified with both nickel and cobalt hydroxides, and have determined their electrocatalytic activity for the oxidation of 2,4,6-trichlorophenol (TCP). As far as we know, no similar studies have been reported.

\section{EXPERIMENTAL SECTION}

2.1 Electrode preparation

Two kinds of glassy carbon electrodes were used as supports, a GC disc (CHInstruments, $0.071 \mathrm{~cm}^{2}$ geometric area) and serigraphied electrodes (Dropsens, $0.130 \mathrm{~cm}^{2}$ geometric area). A one-compartment electrochemical cell with a Pt auxiliary electrode and an $\mathrm{Ag} / \mathrm{AgCl} / \mathrm{KCl}_{\text {sat }}$ reference electrode with a Luggin connection were used. The GC disc electrode was cleaned as previously described [11], whereas the GC-serigraphied electrodes were only washed with bidistilled water. Both types of electrodes were stabilized by repetitive cyclic voltammetry (RCV) at $0.1 \mathrm{~V} \mathrm{~s}^{-1}$ in $0.5 \mathrm{M} \mathrm{H}_{2} \mathrm{SO}_{4}$ until achieving a constant double layer current density and then activated by RCV $(10$ cycles $)$ in Britton-Robinson buffer of a given $\mathrm{pH}$. The $(\mathrm{Ni}-\mathrm{Co})(\mathrm{OH})_{2} / \mathrm{GC}$ electrode was formed indirectly by reduction of the nitrate anion in a $50 \mathrm{mM}$ $(\mathrm{Ni}+\mathrm{Co})$ total concentration of a $\mathrm{Ni}\left(\mathrm{NO}_{3}\right)_{2}+\mathrm{Co}\left(\mathrm{NO}_{3}\right)_{2}$ solution and with an $80 / 20$ or $50 / 50 \mathrm{~mol} / \mathrm{mol} \mathrm{Ni} / \mathrm{Co}$ ratio, using $1.0 \mathrm{M} \mathrm{NaNO}_{3}$, pH 7.2 as support electrolyte, under nitrogen and at room temperature, as reported previously for $\mathrm{Ni}(\mathrm{OH})_{2}$ [25]. Deposition was carried out by RCV (6 cycles) at $0.005 \mathrm{~V} \mathrm{~s}^{-1}$ between -0.4 and $1.2 \mathrm{~V}$. Electrodes of pure nickel hydroxide $\left(\mathrm{Ni}(\mathrm{OH})_{2} / \mathrm{GC}\right)$ and pure cobalt hydroxide $\left(\mathrm{Co}(\mathrm{OH})_{2} / \mathrm{GC}\right)$ were obtained by RCV (6 scans) at 0.005 $\mathrm{V} \mathrm{s}^{-1}$ between -0.4 and $1.2 \mathrm{~V}$ in $0.1 \mathrm{M} \mathrm{NaNO}_{3}$ with $\mathrm{Ni}\left(\mathrm{NO}_{3}\right)_{2}$ and $\mathrm{Co}\left(\mathrm{NO}_{3}\right)_{2}$, respectively.

\subsection{Electrode characterization}

The modified GC-DropSens electrode, coated with a gold film, was characterized by Scanning Electron Microscopy (SEM) with an S440 Leica Microscope, using Energy Dispersive X-ray Spectroscopy (EDS) in selected areas. X-Ray Photoelectron Spectroscopy (XPS) was carried out with a channeltron analyzer CLAM2, at pressures from $10^{-9}$ Torr to ultra high vacuum.

Cyclic voltammetry was carried out at $0.005 \mathrm{~V} \mathrm{~s}^{-1}$ in a Britton-Robinson buffer, pH 9.3. A CHInstruments CHI660C was used for impedance measurements at constant potential with a $5 \mathrm{mV}$ rms sinusoidal modulation in the $10 \mathrm{kHz}-10 \mathrm{mHz}$ frequency range, the frequency being decreased in a logarithmic mode with 10 steps per decade over a period of about $30 \mathrm{~min}$, after which no significant impedance changes had occurred. The impedance data were analyzed with the Autolab, Nova 1.7 software.

\section{RESULTS AND DISCUSSION} films

3.1 Preparation, stabilization and characterization of the $\mathrm{Ni}(\mathrm{OH})_{2}-\mathrm{Co}(\mathrm{OH})_{2}$

3.1.1. Preparation and stabilization of the films.

Although two $\mathrm{Ni}\left(\mathrm{NO}_{3}\right)_{2} / \mathrm{Co}\left(\mathrm{NO}_{3}\right)_{2}$ ratios were used, no great differences were observed, and therefore in Figure 1 only the results for an $80 / 20 \mathrm{Ni} / \mathrm{Co}$ 
ratio are shown. The hydroxide film, formed by RCV at $0.005 \mathrm{~V} \mathrm{~s}^{-1}$, produced a current increase over an extended potential range (Figure 1A). The film-coated electrode was washed with abundant distilled water and stabilized by RCV at $0.1 \mathrm{~V} \mathrm{~s}^{-1}$ in $0.1 \mathrm{M} \mathrm{NaOH}$ (Figure 1B). This stabilization, followed by $5 \mathrm{CVs}$ at $0.005 \mathrm{~V} \mathrm{~s}^{-1}$ in a pH 9.3 Britton-Robinson buffer (Figure1C), yields a CV with clearly defined peaks (Figure 1D). Three anodic peaks appear: $a 1$ at $0.42 \mathrm{~V}$, due to the formation of $\mathrm{Co}(\mathrm{III}) ; a 2$ at $0.62 \mathrm{~V}$, due to the formation of $\mathrm{Co}(\mathrm{IV})$; and $a 3$ at $0.73 \mathrm{~V}$, with its corresponding cathodic peak, $c 3$, due the $\mathrm{Ni}(\mathrm{II}) /$ $\mathrm{Ni}$ (III) process. This peak $c 3$ masks the reduction peaks of $\mathrm{Co}$ (IV) and $\mathrm{Co}(\mathrm{III})$ species. The assignment of the processes is based on the CVs at $0.005 \mathrm{~V} \mathrm{~s}^{-1}$ in a 9.3 buffer electrolyte of a $\mathrm{Ni}(\mathrm{OH})_{2} / \mathrm{GC}$ electrode (Figure $2 \mathrm{~A}$ ) and of a $\mathrm{Co}(\mathrm{OH})_{2} / \mathrm{GC}$ electrode (Figure 2B). The characteristic non-Nerstian $\mathrm{Ni}(\mathrm{III}) /$ $\mathrm{Ni}(\mathrm{II})$ couple [25], with peaks at 0.71 and $0.58 \mathrm{~V}$, corresponds to equation (1) above [16].

The $\mathrm{CV}$ of $\mathrm{Co}(\mathrm{OH})_{2} / \mathrm{GC}$ (Figure 2B) shows two anodic peaks at 0.33 and $0.59 \mathrm{~V}$, with the respective cathodic peaks at 0.31 and $0.56 \mathrm{~V}$, respectively. Zhou et al. [26] attributed these processes to

$$
\begin{aligned}
& \mathrm{Co}(\mathrm{OH})_{2}+\mathrm{OH}^{-} \leftrightarrows \mathrm{CoOOH}+\mathrm{H}_{2} \mathrm{O}+\mathrm{e}^{-} \\
& \mathrm{CoOOH}+\mathrm{OH}^{-} \leftrightarrows \mathrm{CoO}_{2}+\mathrm{H}_{2} \mathrm{O}+\mathrm{e}^{-}
\end{aligned}
$$

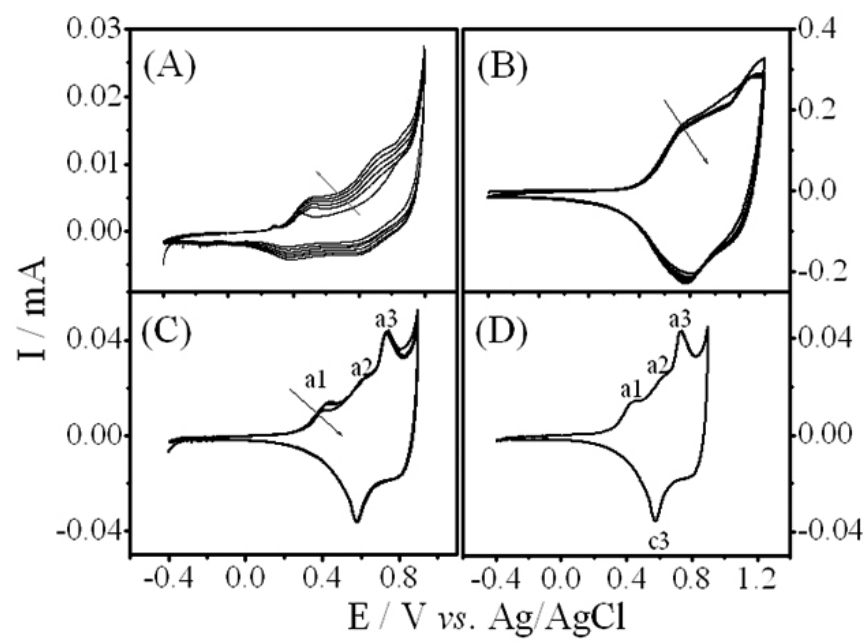

Figure 1: Preparation of the $(\mathrm{Ni}-\mathrm{Co})(\mathrm{OH})_{2} / \mathrm{GC}$ electrode. (A) $\mathrm{RCVs}$ at $0.005 \mathrm{~V} \mathrm{~s}^{-1}$ in in a $50 \mathrm{mM}(\mathrm{Ni}+\mathrm{Co})$ total concentration of a $\mathrm{Ni}\left(\mathrm{NO}_{3}\right)_{2}+$ $\mathrm{Co}\left(\mathrm{NO}_{3}\right)_{2}$ solution and with an $80 / 20$ or $50 / 50 \mathrm{~mol} / \mathrm{mol} \mathrm{Ni} / \mathrm{Co}$ ratio, using 0.1 $\mathrm{M} \mathrm{NaNO}_{3}, \mathrm{pH} 7.2$ as support electrolyte. (B) Stabilization of the $(\mathrm{Ni}-\mathrm{Co})(\mathrm{OH})_{2}$ film by RCV at $0.1 \mathrm{~V} \mathrm{~s}^{-1}$ in $0.1 \mathrm{M} \mathrm{NaOH}$. (C) Stabilization of the $(\mathrm{Ni}-\mathrm{Co})(\mathrm{OH})$ film in a pH 9.3 Britton-Robinson buffer by RCV at $0.005 \mathrm{~V} \mathrm{~s}^{-1}$. (D) Stabilized $\mathrm{CV}$ under the conditions in (C).

It becomes apparent that the $\mathrm{CV}$ of a mixture of $\mathrm{Co}$ and $\mathrm{Ni}$ hydroxides is simply the sum of the individual CVs of the two pure hydroxides.

3.1.2. Electrochemical Impedance Spectroscopy of the films.

Nyquist and Bode plots of electrodes of $(\mathrm{Ni}-\mathrm{Co})(\mathrm{OH})_{2} / \mathrm{GC}$ (Figure $3 \mathrm{~A}$ and $\mathrm{D}$ ), $\mathrm{Co}(\mathrm{OH})_{2} / \mathrm{GC}$ (Figure $3 \mathrm{~B}$ and $\mathrm{E}$ ), $\mathrm{Ni}(\mathrm{OH})_{2} / \mathrm{GC}$ (Figure $3 \mathrm{C}$ and $\mathrm{F}$ ) were obtained at three potentials, $0.45 \mathrm{~V}$ (squares), $0.63 \mathrm{~V}$ (circles) and $0.83 \mathrm{~V}$ (triangles). The Nyquist diagrams (Figure $3 \mathrm{~A} \rightarrow \mathrm{C}$ ) show that at $0.45 \mathrm{~V}$ all the electrodes behave as a constant phase element, this behaviour obtaining also at $0.63 \mathrm{~V}$ for $(\mathrm{Ni}-\mathrm{Co})(\mathrm{OH})_{2} / \mathrm{GC}$ (Figure $3 \mathrm{~A}$ ) and for $\mathrm{Co}(\mathrm{OH})_{2} / \mathrm{GC}$ (Figure 3B) electrodes, whereas in $\mathrm{Ni}(\mathrm{OH})_{2} / \mathrm{GC}$ it is clear that the $\mathrm{Ni}(\mathrm{II}) / \mathrm{Ni}(\mathrm{III})$ process has already started at this potential (Figure 3C). At $0.83 \mathrm{~V}$ charge transfer occurs in all the electrodes, the lower charge-transfer resistance $\left(\mathrm{R}_{\mathrm{H}}\right.$ ) corresponding to the $\mathrm{Co} / \mathrm{GC}$ electrode. It is very interesting that the addition of $\mathrm{Co}$ to the $\mathrm{Ni}$ electrode reduces by a factor of ten its $\mathrm{R}_{\mathrm{F}}$, which so becomes similar to that of $\mathrm{Co}(\mathrm{OH})_{2} / \mathrm{GC}$. The Bode plots (Figure $3 \mathrm{D} \rightarrow \mathrm{F}$ ) show that at $0.45 \mathrm{~V}$ both the $\mathrm{Co}(\mathrm{OH})_{2} / \mathrm{GC}$ and the $(\mathrm{Ni}-\mathrm{Co})(\mathrm{OH})_{2} / \mathrm{GC}$ electrodes have a time constant at high frequencies, which disappears at $0.63 \mathrm{~V}$, when the $\mathrm{Co}(\mathrm{III}) / \mathrm{Co}(\mathrm{IV})$ process is occurring.

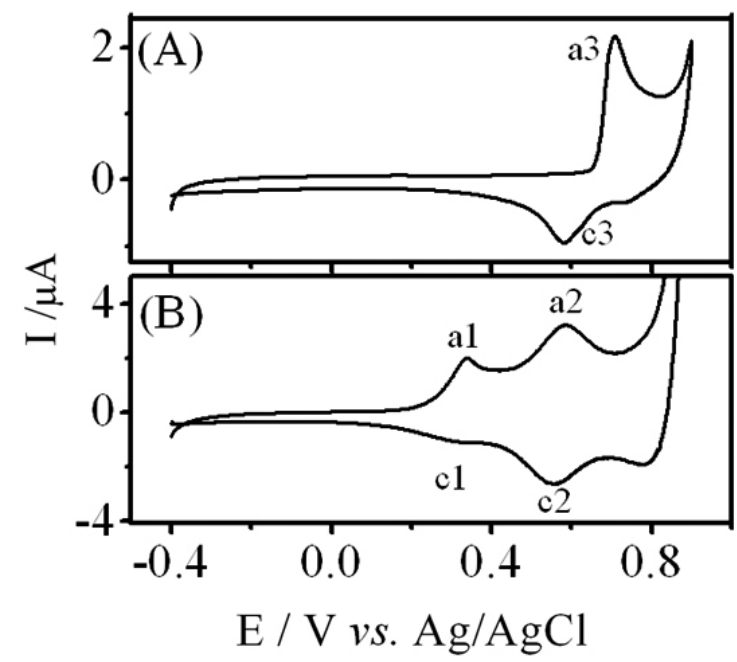

Figure 2. $\mathrm{CV}$ at $0.005 \mathrm{~V} \mathrm{~s}^{-1}$ in a $\mathrm{pH} 9.3$ Britton-Robinson buffer of: (A) $\mathrm{Ni}(\mathrm{OH}) 2 / \mathrm{GC}$ electrode. (B) $\mathrm{Co}(\mathrm{OH}) 2 / \mathrm{GC}$ electrode.

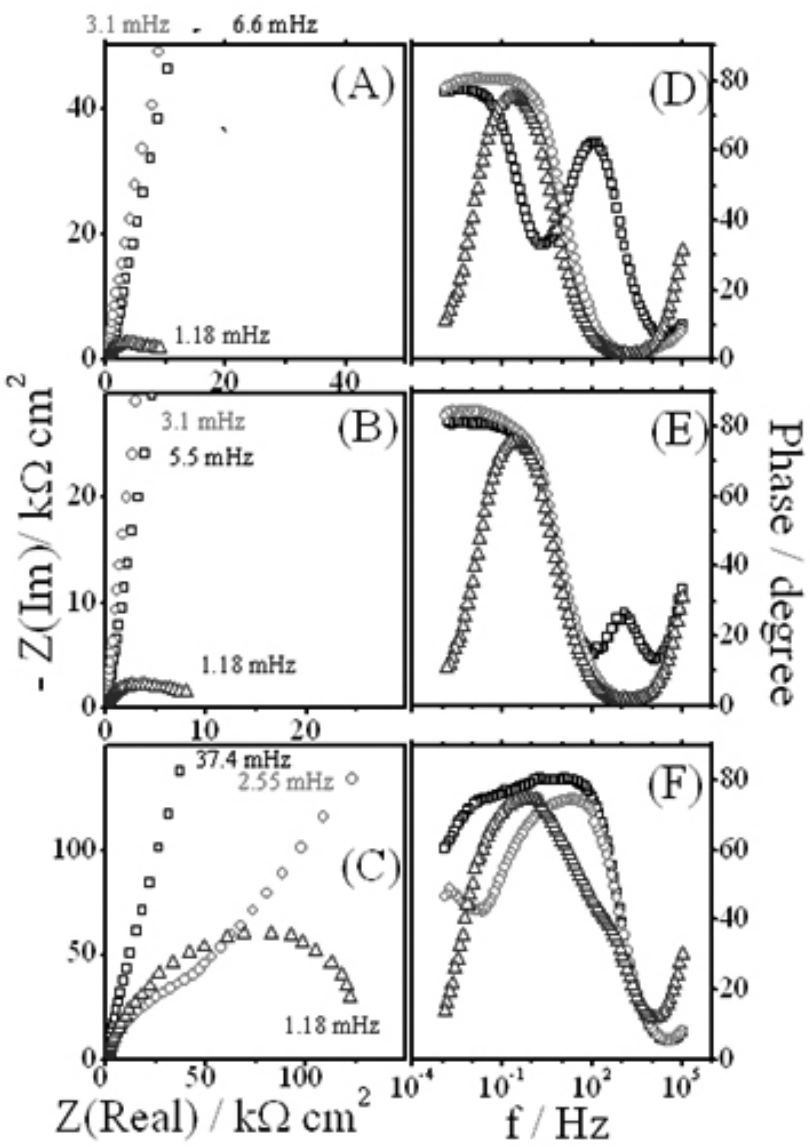

Figure 3. Nyquist plots (A, B and C) and corresponding Bode plots (D, E and $\mathrm{F}$ ) at $0.45 \mathrm{~V}$ (squares), $0.63 \mathrm{~V}$ (circles) and $0.83 \mathrm{~V}$ (triangles) in a $\mathrm{pH} 9.3$ buffer electrolyte of GC electrodes coated with a film of: $(\mathrm{A}, \mathrm{D})(\mathrm{Ni}-\mathrm{Co})(\mathrm{OH})_{2}$; $(\mathrm{B}, \mathrm{E}) \mathrm{Co}(\mathrm{OH})_{2} ;(\mathrm{C}, \mathrm{F}) \mathrm{Ni}(\mathrm{OH})_{2}$. 
3.1.3. SEM of the films.

All the samples were coated with gold in order to increase their conductivity. SEM images of serigraphied GC electrodes (Figure 4 A) show that their surface is made up of flakes, and therefore very rough. The hydroxide films appear as sand spread on these flakes (Figure $4 \mathrm{~B} \rightarrow \mathrm{D}$ ). EDS analysis of different parts of the deposits showed the presence of $\mathrm{Co}$ and Ni (Figure 5). The atomic compositions of the surfaces of the different electrodes are given in Table 1.
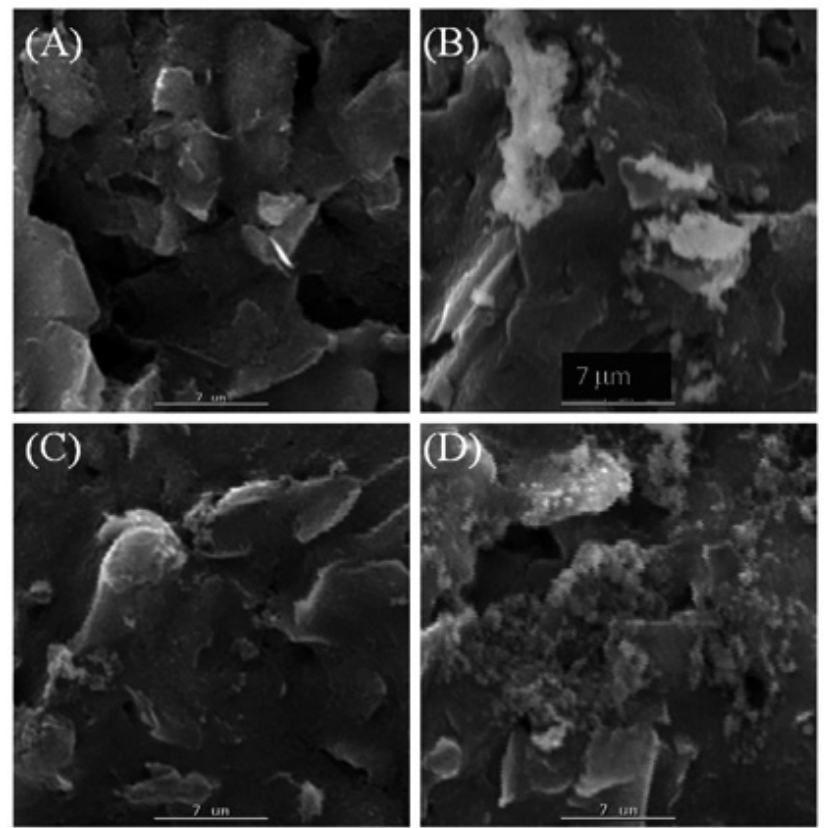

Figure 4. SEM images of: As-received GC serigraphied electrode (A). Asprepared $\mathrm{Co}(\mathrm{OH})_{2} / \mathrm{GC}(\mathrm{B}), \mathrm{Ni}(\mathrm{OH})_{2} / \mathrm{GC}(\mathrm{C})$, and $(\mathrm{Ni}-\mathrm{Co})(\mathrm{OH})_{2} / \mathrm{GC}$ electrodes (D).

Table 1 Atomic composition (atom \% ) of the surfaces of bare GC and of $\mathrm{GC}$ modified with $\mathrm{Ni}(\mathrm{OH})_{2}, \mathrm{Co}(\mathrm{OH})_{2}$ and $(\mathrm{Ni}-\mathrm{Co})(\mathrm{OH})_{2}$ films, as obtained by EDS.

\begin{tabular}{|c|c|c|c|c|}
\hline \multirow{2}{*}{$\begin{array}{c}\text { Atomic } \\
\text { element }\end{array}$} & \multicolumn{5}{|c|}{$\begin{array}{c}\text { Electrode } \\
\text { GC }\end{array}$} & $\begin{array}{c}\mathrm{Ni}(\mathrm{OH})_{2} / \\
\mathrm{GC}\end{array}$ & $\begin{array}{c}\mathrm{Co}(\mathrm{OH})_{2} / \\
\mathrm{GC}\end{array}$ & $(\mathrm{Ni}-\mathrm{Co})(\mathrm{OH})_{2} / \mathrm{GC}$ \\
\hline $\mathrm{C}$ & 80 & 73 & 1.9 & 49 \\
\hline $\mathrm{Cl}$ & 20 & 10 & 13 & 8.8 \\
\hline $\mathrm{O}$ & - & 6.3 & 16 & 7.7 \\
\hline $\mathrm{Ni}$ & - & 11 & - & 6.1 \\
\hline $\mathrm{Co}$ & - & - & 69 & 28 \\
\hline
\end{tabular}

The $\mathrm{Co} / \mathrm{Ni}$ ratio in the $(\mathrm{Ni}-\mathrm{Co})(\mathrm{OH})_{2}$ films is 4.6. This cannot be due to solubility differences, since the $\mathrm{pK}_{\mathrm{sp}}$ constant of $\mathrm{Co}(\mathrm{OH})_{2}(14.8)$ is only slightly lower than that of $\mathrm{Ni}(\mathrm{OH})_{2}(15.3)$, and consequently the solubility of the former is only $50 \%$ higher than that of the latter [27]. Therefore, the high $\mathrm{Co} /$ $\mathrm{Ni}$ ratio should be due to a higher deposition rate of $\mathrm{Co}(\mathrm{OH})_{2}$.

3.1.4. XPS of the films.

The wide-scan XPS spectra of both bare and $(\mathrm{Ni}-\mathrm{Co})(\mathrm{OH})_{2}$-coated GC electrodes are given in Figure 6A. The spectrum of bare GC shows a strong carbon signal $(85 \%)$ and a moderate $\mathrm{Cl}$ contribution $(12 \%)$, which, according to the binding energy of the main $\mathrm{Cl} 2 \mathrm{p}_{32}$ core level, corresponds to chloride ions. A tiny oxygen contribution (3\%) is also observed. The spectrum of the modified electrode shows additional $\mathrm{Co}$ and $\mathrm{Ni}$ photoemission and Auger lines. The surface concentrations of the different elements estimated from this spectrum are: $\mathrm{C}, 63 \%$; $\mathrm{O}, 33 \%$; $\mathrm{Co}, 2.5 \%$; Ni, $0.5 \%$; and $\mathrm{Cl}, 1 \%$. The sparse coverage of hydroxides agrees with the SEM micrographs of Figure 4. The Co/ Ni ratio is within $10 \%$ of that evaluated by SEM-EDS.
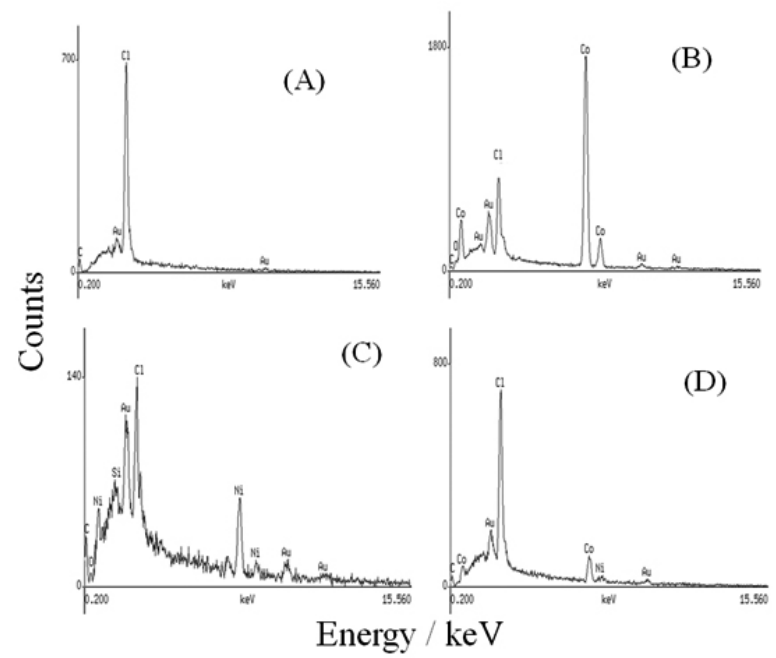

Figure 5. EDS analysis of the samples in Figure 4.

The high-resolution spectra of the Co $2 p$, Ni $2 p$ and $\mathrm{O} 1$ s core levels are given in Figure 6B-D. The Co 2p spectrum (Figure 6B) is rather complex, showing two spin-orbit doublets and several shake-up satellites (the dashed and dotted lines are the contributions of $\mathrm{Co}^{3+}$ and $\mathrm{Co}^{2+}$, respectively). The spin-orbit doublet characterized by binding energies of the Co $2 \mathrm{p} 3 / 2$ and Co $2 \mathrm{p} 1 / 2$ core levels of $779.9 \mathrm{eV}$ and $795.0 \mathrm{eV}$, together with the small shake-up satellite peak at $790.0 \mathrm{eV}$, is characteristic of $\mathrm{Co}^{3+}[28,29]$. The broader spin-orbit doublet with binding energies of $781.5 \mathrm{eV}(\mathrm{Co} 2 \mathrm{p} 3 / 2)$ and $796.7 \mathrm{eV}(\mathrm{Co} 2 \mathrm{p} 1 / 2)$ and the two strong shake-up satellites at $785.4 \mathrm{eV}$ and $802.3 \mathrm{eV}$ are assigned to $\mathrm{Co}^{2+}$ $[28,29]$. The $\mathrm{Co}^{2+}$ and $\mathrm{Co}^{3+}$ relative concentrations obtained from the fitting of this spectrum are $62 \%$ and $38 \%$, respectively.

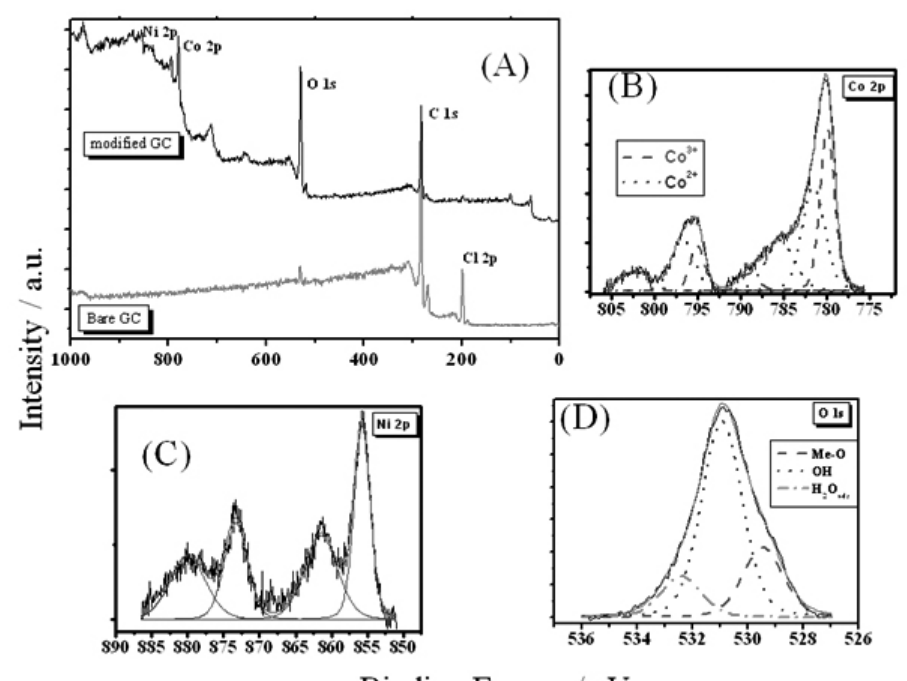

Binding Energy / eV

Figure 6. (A) Ex situ XPS spectra of an untreated GC serigraphied electrode and of the former coated with an as-prepared $(\mathrm{Ni}-\mathrm{Co})(\mathrm{OH})$ film. Expanded regions of the XPS spectrum of the $(\mathrm{Ni}-\mathrm{Co})(\mathrm{OH})_{2} / \mathrm{GC}$ electrode: $(\mathrm{B})$ Expanded Co2p region, (C) Expanded Ni2p region, and (D) Expanded O1s region.

The Ni $2 p$ spectrum (Figure 6C) shows only one spin-orbit doublet with binding energies of $855.8 \mathrm{eV}(\mathrm{Ni} 2 \mathrm{p} 3 / 2)$ and $873.2 \mathrm{eV}(\mathrm{Ni} 2 \mathrm{p} 1 / 2)$ and two intense shake-up satellites at approximately $6 \mathrm{eV}$ above these main photoemission lines. All these spectral features are compatible with the presence of $\mathrm{Ni}(\mathrm{OH})_{2}[30,31]$. In this respect, it is interesting to note that the $\mathrm{O}$ $1 \mathrm{~s}$ spectrum (Figure $6 \mathrm{D}$ ) of the modified electrode shows three contributions. 
The most intense one (64\%) corresponding to metal-OH bonds $(530.9 \mathrm{eV})$, which supports the assignment to $\mathrm{Ni}(\mathrm{OH})_{2}$ (and, most likely, supports also the presence of $\left.\mathrm{Co}(\mathrm{OH})_{2}\right)$. The binding energy at $529.5 \mathrm{eV}(23 \%)$ is characteristic of a metal $=\mathrm{O}$ double bond $[28,29]$ and, if we take into account the above results, it could be due to $\mathrm{CoOOH}$. The third contribution at $532.4 \mathrm{eV}(13 \%)$ is typically associated with adsorbed water $[28,29]$.

Finally, both SEM-EDS (mass analysis) with XPS (surface analysis) yielded nearly the same $\mathrm{Co} / \mathrm{Ni}$ ratio, supporting a homogeneous distribution of the two hydroxides in the film.

3.2. Electrooxidation of 2,4,6-trichlorophenol (TCP)

3.2.1. Cyclic voltammetry.

We had already reported [10] that the active species in the oxidation of TCP at glassy carbon electrodes is the phenolate anion, and therefore $\mathrm{pHs}$ higher than the pKa of 2,4,6-TCP, 7.7 [27], should be used. Previous results indicate that in cyclic voltammetry experiments there is diffusional control in the first electron transfer but that phenolic oligomers formed afterwards foul the electrode. Therefore, the goal is to favor the second charge transfer, so avoiding the formation of oligomers. Using Britton-Robinson buffers of different $\mathrm{pH}$ values, it was found that the optimum $\mathrm{pH}$ for the oxidation of $1 \mathrm{mM}$ TCP on $\mathrm{Ni}-\mathrm{Co} / \mathrm{GC}$ electrodes was 9 , because at this $\mathrm{pH}$ TCP reacts at the potentials of the $\mathrm{Co}(\mathrm{III}) / \mathrm{Co}(\mathrm{IV})$ and of $\mathrm{Ni}(\mathrm{II}) / \mathrm{Ni}(\mathrm{III})$ reactions (Figure 7$)$. In the negative scan two new cathodic peaks are observed, $c 4$ and $c 5$, due to the reduction of two different quinones to the respective hydroquinones, as confirmed using commercial 2,6-dichloro-1,4-hydroquinone and 2-chloro-1,6-hydroquinone.

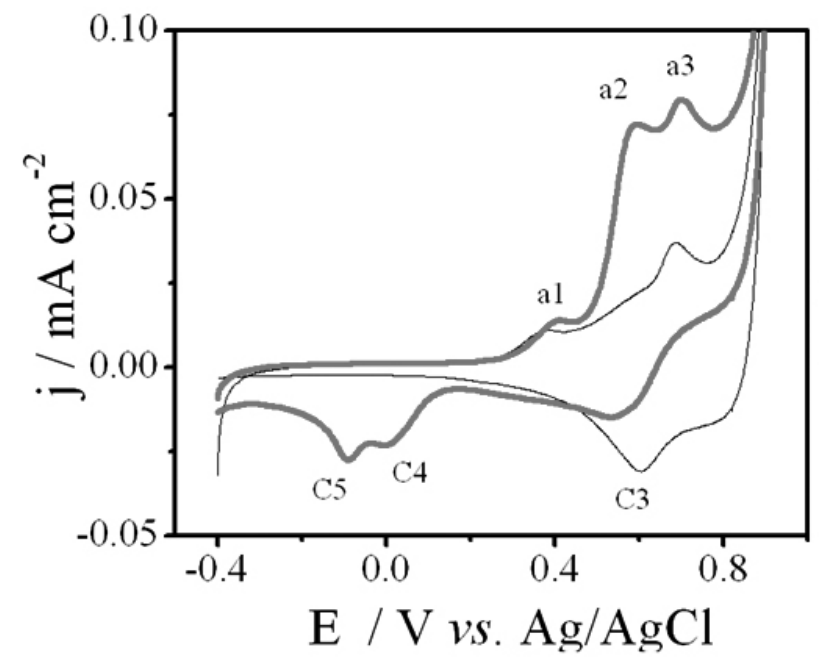

Figure 7. Cyclic voltammograms at $0.005 \mathrm{~V} \mathrm{~s}-1$ of a $(\mathrm{Ni}-\mathrm{Co})(\mathrm{OH})_{2} / \mathrm{GC}$ electrode in a $\mathrm{pH} 9.3$ Britton-Robinson buffer (thin solid line) and in the presence of $1 \mathrm{mM}$ TCP (thick solid line).

The CVs at $0.005 \mathrm{~V} \mathrm{~s}^{-1}$ of a (Ni-Co)(OH) $/ 2$ GC electrode in $\mathrm{pH} 9.3$ buffer electrolyte, before (thin solid line) and after (thick solid line) $5 \mathrm{CVs}$ in the presence of $1 \mathrm{mM} \mathrm{TCP}$, are shown in Figure 8. Although some reaction products with a quinone/hydroquinone structure remain adsorbed on the electrode surface (peaks $c 5$ and a5), the activity of the $\mathrm{Co}$ and $\mathrm{Ni}$ processes remain practically unaltered, indicating that the electrode had not become coated with phenolic oligomers, or that, if present, these are very porous.

The onset potentials at $0.005 \mathrm{~V} \mathrm{~s}^{-1}$ in $1 \mathrm{mM} \mathrm{TCP}$ in a pH 9 buffer electrolyte are similar for $\mathrm{Co}(\mathrm{OH})_{2} / \mathrm{GC}(0.44 \mathrm{~V})$ and $\mathrm{Ni}(\mathrm{OH})_{2} / \mathrm{GC}(0.45 \mathrm{~V})$ electrodes (not shown). The onset potential at the $(\mathrm{Ni}-\mathrm{Co})(\mathrm{OH})_{2}$ electrode is the same, $0.46 \mathrm{~V}$, but then the current increases much more rapidly.

3.2.2. Electrochemical Impedance Spectroscopy.

The Nyquist $(\mathrm{A} \rightarrow \mathrm{C})$ and Bode $(\mathrm{D} \rightarrow \mathrm{F})$ plots at $0.451 \mathrm{~V}$ in $\mathrm{pH} 9.3$ buffer (filled symbols) and in the presence of $1 \mathrm{mM} \mathrm{TCP}$ (open symbols) are shown in Figure 9 for the three electrodes. In all cases the charge-transfer resistance decreases in the presence of TCP, which evidences its oxidation. The lowest charge-transfer resistance was that of the $\mathrm{Co} / \mathrm{GC}$ electrode (Figure 9B). The $\mathrm{R}_{\mathrm{F}}$ of the $(\mathrm{Ni}-\mathrm{Co})(\mathrm{OH})_{2} / \mathrm{GC}$ electrode (Figure $9 \mathrm{~A}$ ) is lower than that of the $\mathrm{Ni}(\mathrm{OH})_{2} / \mathrm{GC}$ electrode (Figure 9C), which agrees with the hypothesis that the presence of Co favours the conductivity across the $\mathrm{Ni}(\mathrm{OH})_{2}$ films, thereby improving the performance. Please note that at the higher frequencies the Bode plot of the $\mathrm{Co}(\mathrm{OH})_{2} / \mathrm{GC}$ electrode changes dramatically in the presence of TCP, whereas those of $(\mathrm{Ni}-\mathrm{Co})(\mathrm{OH})_{2} / \mathrm{GC}$ and $\mathrm{Ni}(\mathrm{OH})_{2} / \mathrm{GC}$ electrodes do not. The system is so complex that a reasonable equivalent circuit cannot be obtained.

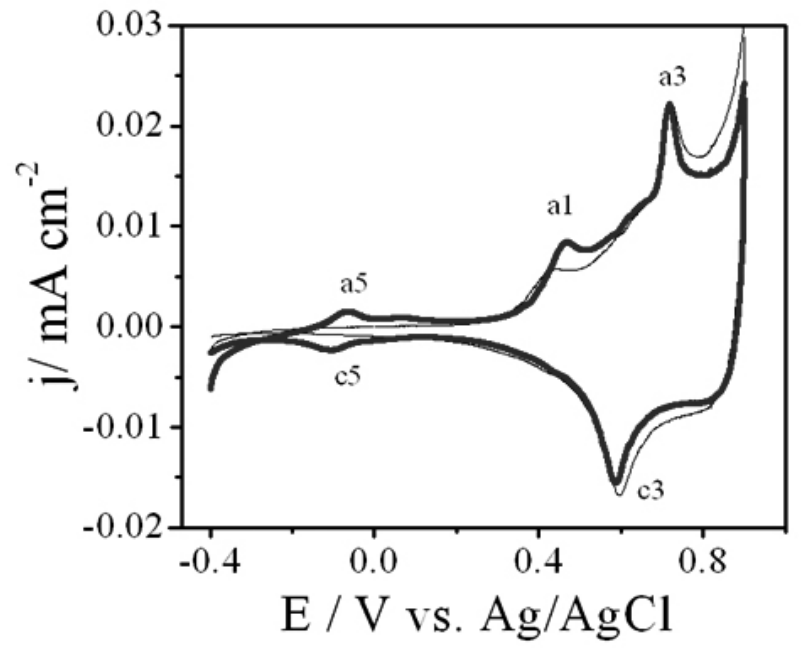

Figure 8. Cyclic voltammetry at $0.005 \mathrm{~V} \mathrm{~s}-1$ of a $(\mathrm{Ni}-\mathrm{Co})(\mathrm{OH})_{2} / \mathrm{GG}$ electrode in a pH 9.3 Britton-Robinson buffer before (thin solid line) and after (thick solid line) $5 \mathrm{RCVs}$ in the presence of $1 \mathrm{mM}$ TCP.

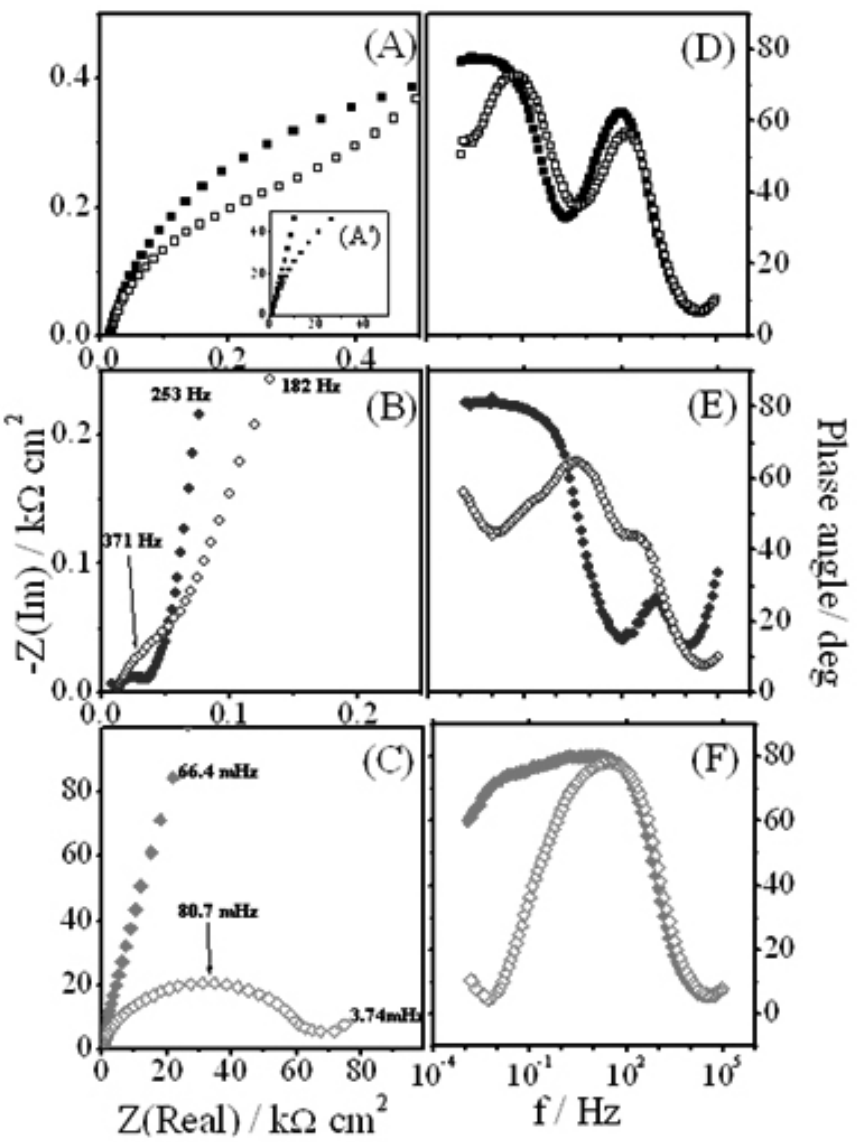

Figure 9. Nyquist $(\mathrm{A} \rightarrow \mathrm{C})$ and Bode $(\mathrm{D} \rightarrow \mathrm{F})$ plots at $0.451 \mathrm{~V}$ in a $\mathrm{pH} 9.3$ buffer (closed symbols) and in the presence of $1 \mathrm{mM} \mathrm{TCP}$ (open symbols) for the following electrodes: (A) and (D), $(\mathrm{Ni}-\mathrm{Co})(\mathrm{OH})_{2} / \mathrm{GC}$; (B) and (E), $\mathrm{Co}(\mathrm{OH})_{2} / \mathrm{GC} ;(\mathrm{C})$ and $(\mathrm{E}), \mathrm{Ni}(\mathrm{OH})_{2} / \mathrm{GC}$. 


\section{4.- CONCLUSION}

4.1 Surface characterization

Both XPS and SEM show that in the mixed film $\mathrm{Ni}(\mathrm{OH})_{2}$-like and $\mathrm{Co}(\mathrm{OH})_{2}-$ like compounds coexist. Independently of the initial $\mathrm{Ni}^{2+} / \mathrm{Co}^{2+}$ ratio in the electrolyte, the $\mathrm{Co} / \mathrm{Ni}$ ratio in the film is about 4.6, indicating that the $\mathrm{Co}(\mathrm{OH})_{2}$ precipitation is much faster. It was found by $\mathrm{CV}$ that in $(\mathrm{Ni}-\mathrm{Co})(\mathrm{OH})_{2}$ films each hydroxide behaves as in its pure state.

4.2. Oxidation of 2,4,6-TCP

The mixed (Ni-Co)(OH) , film promotes a more complete oxidation of TCP, facilitating the formation of the corresponding quinones, which substantially decreases the fouling of the electrode surface.

\section{ACKNOWLEDGEMENTS}

The financial support of CONICYT-Chile, under Project FONDECYT 1100476 , is gratefully acknowledged.

\section{REFERENCES}

1. A. Kapałka, G. Fóti, C. Comninellis, in "Electrochemistry for the Environment". C. Comninellis and G. Chen, Editors, Springer, New York. 2010. Chaps. 1 and 2.

2. S. Budavari, M. J. O"Neil, A. Smith, P. E. Heckelman. "The Merck Index", 11th Ed., 1989, pags. 332, 484, 1517.

3. N. S. Kumar, K. Min, J. Chil. Chem. Soc. 56 (2011) 539-545.

44 M.S. Ureta-Zañartu, P. Bustos, M.C. Diez, M.L. Mora, C. Gutiérrez, Electrochim Acta 46 (2001) 2545-2551.

5. M.S. Ureta-Zañartu, P. Bustos, C. Berrios, M.C. Diez, M.L. Mora, C. Gutiérrez, Electrochim. Acta 47 (2002) 2399-2406.

6. J. M. Zen, A. S. Kumar, D. M. Tsai.. Electroanalysis, 15 (2003) 1073-1087.
7. T. Mafatle, T. Nyokong, Anal.Chimica Acta, 354 (1997) 307-314

8. A. Alatorre, F. Bedioui, S. Gutiérrez, Bol. Soc. Chil. Quim., 43 (1998) 375-390.

9. M.S. Ureta-Zañartu, C. Berríos, J. Pavez, J. Zagal, C. Gutiérrez, J. Marco, J. Electroanal. Chem. 553 (2003) 147-156.

10. C. Berrios, R. Arce, M.C. Rezende, M.S. Ureta-Zañartu, C. Gutiérrez, Electrochim. Acta 53 (2008) 2768-2775.

11. C. Berríos, J.F. Marco, C. Gutiérrez, M.S. Ureta-Zañartu, Electrochim. Acta 54 (2009) 6417-6425.

12. M. Fleischmann, K. Korinek, D. Pletcher, J. Electroanal. Chem. 31 (1971) 39-49.

13. S. Deabatea, F. Fourgeot, F. Henn, Electrochim. Acta 51 (2006) 54305437.

14. A.A. El-Shafei, J. Electroanal. Chem. 471 (1999) 89-95.

15. V. Srinivasan, B. C. Cornilsen, J. W. Weidner, J. Solid State Electrochem. 9 (2005) 61-76

16. A. Van der Ven, D. Morgan, Y. S. Meng, G. Cederc, J. Electrochem. Soc., 153 (2006) A210-A215.

17. A.B. Yuan, N.X. Xu, J. Appl. Electrochem., 31 (2001) 245-250.

18. X. Li, S. Li, J. Li, H. Dong, J. Appl. Electrochem., 39 (2009) 377-381.

19. X. Li, H. Dong, J. Li, X. Tongchi, J. Appl. Electrochem., 40 (2010) 73-77.

20. M. Jafarian, M.G. Mahjani, H. Heli, F. Gobal, H. Khajehsharifi, M.H. Hamedi, Electrochimica Acta 48 (2003) 3423-3429.

21. M. Jafarian, M.G. Mahjani, H. Heli, F. Gobal, M. Heydarpoor, Electrochem. Comm, 5 (2003) 184-188

22. J. Ortiz, M. Puelma, J.L. Gautier, J. Chil. Chem. Soc. 48 (2003) 67-71.

23. M. Vidotti, M.R. Silva, R.P. Salvador, S.I. Córdoba de Torresi, L.H. Dall'Antonia, Electrochim. Acta 53 (2008) 4030-4034.

24. W. Yan, D. Wang, G.G. Botte, Electrochim. Acta, 61 (2012) 25-30.

25. M. S. Ureta-Zañartu, T. González, F. Fernández, D. Báez, C. Berríos, C. Gutiérrez, Inter. J. Electrochem. Sc., 7, (2012) 8794-8812. 